\title{
Calvinism, atheism and freedom of religion: A South African perspective
}

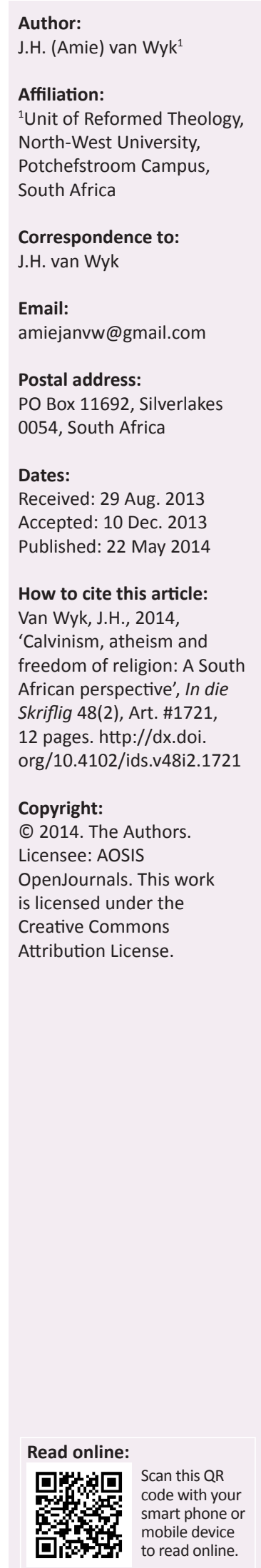

In this article the author investigates the approaches of Calvinism and atheism regarding the freedom of religion. The different views on God, man and science according to these worldviews function as a background for the explanation of freedom of religion. Special attention is been paid to the South African Constitution of 1996 and the stipulations of this constitution regarding freedom of religion for churches and schools. The article ends with a few concluding remarks and suggestions for further investigation.

Calvinisme, ateïsme en godsdiensvryheid: 'n Suid-Afrikaanse perspektief. Hierdie artikel ondersoek die benaderings van Calvinisme en ateïsme ten opsigte van godsdiensvryheid. Die verskillende sienings oor God, mens en wetenskap funksioneer as agtergrond vir 'n uiteensetting van godsdiensvryheid. Besondere aandag word aan die Suid-Afrikaanse Grondwet van 1996 geskenk, asook die bepalings van hierdie grondwet vir kerke en skole. Die artikel sluit af met 'n paar slotopmerkings en voorstelle vir verdere ondersoek.

\section{Introduction: A new debate}

With the rise of atheism, and lately antitheism during the last decades, this movement can no longer be ignored in theological reflection and discourse. Since the publication of Richard Dawkins's sensational and influential book, The God delusion (2007), the question about the existence of God, his creation, revelation and providence, his salvation and sanctification has been challenged as never before. In the eyes of many modern people he is an outdated and even dangerous character. His laws are irrelevant and immoral and it is no longer self-evident to speak about God. Theology is challenged as never before to supply meaningful answers to these fundamental questions.

In the South African context, the book of George Claassen titled Faith, superstition and wishful thinking (2008) drew much attention, and lately also the outspoken and aggressive book of the Stellenbosch atheist Hans Pietersen (2011) on 'the fear of the fathers', which focuses on religious education of Afrikaner children in South Africa. ${ }^{2}$ This article also refers to the book published by George Claassen and Frits Gaum on God? Conversations on the origin and the end of everything (2012), written by Christians and atheists without any real interaction between the two groups. Armando Pellencin's book (2007) is not much in discussion, but it offers a well-written explanation of the atheistic option. ${ }^{3}$

The question arises, of what stance should be taken by Calvinists and atheists as far as religious freedom is concerned. Calvinism and atheism are two conflicting worldviews and two opposing belief systems, which raises the question: How should societies be organised so that people can live in peace?

\section{Calvinism ${ }^{4}$}

Calvinism is usually defined by the five well-known 'solisms': soli Deo Gloria, solo Christo, sola gratia, sola fide and sola Scriptura - sometimes with a strong emphasis on the sovereignty of

1.The first draft of this article was presented at a meeting of the International Reformed Theological Institute, which was held in Sárospatak, Hongary on 02-06 July 2013. The revised article is now dedicated to my colleague, Herry van Rooy, in appreciation for his great contribution to the field of Old Testament studies.

2.This article will refer to a great extent to this book, because the views of other atheists have already been discussed in another article (Van Wyk 2013). That article argued that atheism does not supply us with (scientific) satisfactory answers on the five fundamental questions in human life: (1) How do we achieve knowledge and truth? (epistemology); (2) What is the origin of everything? questions in human life: (1) How do we achieve knowledge and truth? (epistemology); (2) What is the origin of everything?
(cosmogony); (3) What is the future of everything? (futurology); (4) What is the meaning of life? (teleology); (5) How do we discern between good and evil? ('ethicology'). Pietersen (2011:198) refers to his approach as atheist, agnostic, apatheist, free thinker, sceptic, between good and evil? ('ethicology') 3.See Mollett, Grundling and Van Heerden (2004). Also see De Villiers (2009:5) for the recently established Vereniging vir Voorstedelike
Afrikaanse Ateïste (VVAA; [Society of Suburban African Atheists]).

4.The author prefers the concept Christian faith, but uses the concept Calvinism for the sake of argument. 'Calvinism' refers to that branch of Christianity that originated during the Reformation of the 16th century under the leadership of John Calvin. 
God (Kuyper 1959:63). Together these solisms form the key features of the theology of John Calvin (1509-1564), Swiss reformer of the 16 th century. ${ }^{5}$

It must be emphasised that 'Calvinism' is a branch of Christianity, which started more than 2000 years ago. It implies that not every idea is a new discovery. God, Jesus Christ, the Holy Spirit, the Bible and the church are topics discussed, considered and meditated on for many centuries. Calvin himself correlated considerably with the theology of Augustine (354-430), who was on his part intensely influenced by the 'theology' of Paul - especially on sin and grace.

In the Christian tradition there was no question whether God exists or not, and whether Christ is Saviour or not. However, the question was with regard to how the grace of God, through Christ, reaches human beings: through the church, sacraments and offices (Roman Catholic approach), or through the proclamation of the gospel, which is embraced in faith through the power of the Holy Spirit (Calvinist approach).

Calvin deals with the relationship between (the almighty and loving) God and (sinful) human beings who are created in the image of God and in the light of God's revelation. Calvin (1960) starts his famous Institutes (Inst.) with the following formulation: 'Nearly all the wisdom we possess, that is to say, true and sound wisdom, consists of two parts: the knowledge of God and of ourselves' (Inst. 1.1). Human beings are irreducible religious beings with a sensus divinitatis [sense of divinity]. They are expected to serve God and proclaim the Lordship of Christ in all spheres of life. Calvin even goes so far as to argue that civil government must cherish and protect the outward worship of God, and defend the sound doctrine of piety and the position of the church (Inst. 4.20.2, $4.20 .3,4.20 .9,4.20 .24)$.

Calvin made an effort to realise these views in the Geneva of his day where he tried to reshape the society of the city into a form of a (realistic) theocracy, although he did not fully succeed (cf. Selderhuis 2008:54).

This invokes the question whether this approach does not violate the idea of religious freedom - in view also of what happened to Servetus, who was condemned to death by the authorities of Genève and burned to death with the approval of Calvin in 1553 (cf. Selderhuis 2008:161-162).

Calvin explicitly dealt with the topic of 'Christian freedom', with a strong emphasis on the freedom of conscience (Inst. 3.19). He had no problem with the use of gold, wealth and possessions as gifts of God, and to laugh, to possess and to wine is nowhere prohibited in Scripture - as long as it is not overdone (Inst. 3.19.9).

Following in the footsteps of Calvin, a form of Neo-Calvinism was developed in the Netherlands by Abraham Kuyper

5.See for instance the following overviews on Calvin: Wendel (1978), Niesel (1980) Wallace (1988), McGrath (1991), Cottret (2000) and Selderhuis (2009).
(1837-1920), who argued that not an inch of life falls outside the rule of Christ. ${ }^{6}$ This approach found fertile ground during the 20th century in South Africa where many Neo-Calvinists erected Christian National Schools $(\mathrm{CNS})^{7}$ and aimed at Christianising the whole of society.

The following examples can illustrate this approach:

- The Education Act 39 of 1967 adopted by Parliament (Van Wyk 2006:347).

- The law (Act 1974) that regulated the South African educational system for whites mandated the ideology of Christian national education (Vorster 2004:222).

- The South African Publications Act of 1974 (on censorship) refers to the fact that the population of South Africa 'upholds a Christian view of life' (Kearney 1991:126).

- The Preamble of the 1983 Constitution of South Africa refers to 'uphold Christian values and civilized norms' (Kearney ibid:126).

During the 20th century, Calvinism developed a very controversial connotation in the South African context because of the involvement of some of its supporters in the ideology of apartheid, and especially because of the theological justification thereof. Prominent theologians and leaders in the three Afrikaans Churches provided a theological justification of the system. ${ }^{8}$ The following names can be mentioned in this regard: E.P. Groenewald, F.J.M. Potgieter, A.B. du Preez and A.P. Treurnicht (Nederduitse Gereformeerde Kerk [NGK]), H.P. Wolmarans and P.S. Dreyer (Nederduitsch Hervormde Kerk van Afrika [NHKA]), and J.D. du Toit ${ }^{9}$ and H.G. Stoker (Gereformeerde Kerke in Suid-Afrika [GKSA]).

The conservative politician Albert Hertzog even made a sensational (and much debated) speech in Parliament in 1969 in which he argued that the survival of the European civilisation (in South Africa) depends on the Afrikaner Calvinists because of their love of freedom and recognition of racial diversity (Giliomee 2003:557-558). ${ }^{10}$

However, not all Calvinists followed this delineation of Calvinism. Critics like Beyers Naudé (from outside the NGK; cf. Naudé 1995; Ryan 1990; Vosloo 2013:253-256), Willie Jonker (a staunch insider; cf. Jonker 1998; Duursema 2012;

6.See Kuyper (1880:32). It is interesting to note that Kuyper views Calvinism in favour of mixed marriages (Kuyper 1959:27-29), that he is against a national church ('volkskerk') and in favour of ecumenism (Kuyper 1959:52). He a nationa church ('volkskerk') and in favour of ecumenism (Kuyper 1959:52). He argues that Calvinism favours the development of science (Kuyper 1959:89-116). Another kind of theocracy is found in Van Ruler (1971:164-177; cf. Van de Beek 2012:102-103) which also influenced South African theologians, like Van Rooyen (1964) and
Engelbrecht (1978; 1982).

7.It must always be kept in mind that the origin of the early CNS movement must be seen as a reaction against the post-war (Anglo Boer War from 1899 to 1902) approach of Milner to 'Anglisise' the South African schools (Giliomee 2003:269272 ; cf. pp. 370 and 468-469). Pietersen (2011) seems to be totally unaware of this fact, because he never refers to it whilst criticising the CNS movement.

8.For short summaries with many source references, see Van Wyk (1993:39-60), Smit (2007:104-107) and Pretorius (2012:453-452). Also see Brits and d'Assonville (2009a; 2009b).

9.Du Toit (Totius) was not the first instigator of an apartheid theology (Smit 2007:19; Pretorius 2012:446) with his presentation of 'Die godsdienstige grondslag van ons rassebeleid' in 1944 in Bloemfontein (Du Toit 1977:330-343). The first to develop this idea were reverends F.G. Badenhorst (1939) and J.G. Strydom $(1941,1942)$ of the NGK and/or DRC.

10.For 'another perspective' on apartheid, see H. Giliomee (2012:429-441). 
Vosloo ibid:256-259) and many others ${ }^{11}$ strongly opposed this unbiblical, unchristian and natural form of theology. Potchefstroom activists involved in the magazine Woord en Daad [Word and Action] as well as the Afrikaanse Calvinistiese Beweging [Afrikaans Calvinist Movement] became more and more critical about apartheid. ${ }^{12}$ Therefore, it is not insignificant that it was a Calvinist from this background, namely F.W. de Klerk who finally brought an end to the system of apartheid on 02 February 1990. De Klerk became convinced that he could no longer live in good conscience whilst tolerating a system of injustice that violated and distorted human dignity (De Klerk 1998:59, 110, 167, 169, 178).

From a theological perspective, apartheid received its final blow when the NG Sendingkerk (DR Mission Church) accepted the Belhar Confession in 1986, which deals with unity, reconciliation and justice.

\section{Atheism}

Scientific atheism is a modern phenomenon. Atheism, as we experience it today, does not appear in the Bible. ${ }^{13}$ The Bible deals with the monotheism of Israel and the polytheism of the gentiles. ${ }^{14}$

Modern scientific atheism originated in the 18th century with the rise of the Aufklürung [Age of Enlightenment] and the entrance of rationalism (Armstrong 2009:203-226; Collins 2007:162), but philosophers of this period were inclined to be more deists than atheists. They believed in God (Armstrong 1999:34), but it was the far-away God of deism (Armstrong 2009:204). Immanuel Kant (1724-1804) was the first philosopher in the West who criticised and rejected the scientific 'proofs of God' and argued that God could only be known by 'practical reason' and not by 'critical/theoretical reason' (Armstrong 1999:369).

Because of the emphasis on human autonomy and rationalism during the Aufklärung, the theme of atheism became more prominent in the 19th and 20th centuries:

11. Hofmeyr (2012:447) refers to the following forerunners: J. du Plessis, B.B. Keet B.J. Marais and A. van Selms, followed by Beyers Naudé, Albert Geyser, Lourens du Plessis, Nico Smith, David Bosch, Amie van Wyk and Johan Heyns. Gaum (2011:110) mentions the following names: Bennie Keet, Ben Marais, André Hugo, Albert Geyser, Beyers Naudé, Willie Jonker, Nico Smith, Amie van Wyk, Willie Esterhuyse, Adrio König, Ferdinand Deist, Piet Meiring, Willem Nicol, Bobby Loubser, Christin Landman, et cetera. Meiring (1999:289) referred to the fact that four reformed theologians, namely Alwyn du Plessis, Amie van Wyk, Bennie van der Walt and Ponti Venter made a submission to the South African Truth and Reconciliation Ponti Venter made a submission to the South African Truth and Reconciliation Commission in 1997 - although only the last two presented it to the Commission. osloo (2013:251) correctly draws attention to the fact that an oversimplified and uncritical acceptance of the 'Calvinist paradigm' (by South African theologians) is problematic. Also see Nico Smith (2010:187-201), who describes how he departed from the 'Afrikanergod' of his fathers, that is, the Calvinist, reformed and electin God. This criticism was from an 'outsider', for Smith later on joined the NGKA.

12.See the following remarks: In Potchefstroom 'probably more of the original Calvin has survived than anywhere else [in South Africa]' (De Klerk 1976:342). 'Especially in the academic and theological circles of Potchefstroom and the Reformed Church (Gereformeerde Kerk) the shift from an apartheid theology to a less apartheidorientated and more critical theology is evident' (Durand 1985:50). Of the three Afrikaans churches, the Gereformeerde Kerke tried 'the most seriously to proclaim the truth of the gospel with regard to race relations and human rights' (Naudé 1985:172-173). Also see Vosloo (2013:249). See in this regard the Public Confession of Guilt of 1997 by four 'Potchefstromers' (Van Wyk 1998:365-367).

13.The atheism to which Psalm 14 refers can be typified as practical atheism and not the theoretical atheism that we experience today (cf. Ridderbos 1962:159).

14.Some researchers accuse Israel of starting off with polytheism and ending up with monotheism (with which I disagree), but that is a story for another day.
- Ludwig Feuerbach (1804-1872) viewed the idea of God as wish fulfilment and a projection of the human mind.

- Karl Marx (1818-1883) argued that religion is the opium of the people.

- Friedrich Nietzsche (1840-1900) declared triumphantly that the (metaphysical) God is dead.

- Sigmund Freud (1856-1939) considered religious faith in God an illusion and a projection of infantile desires.

Add to this the influence of Charles Darwin (1809-1882) and the genesis of the evolution theory, and you have one of the greatest reasons for the origin of atheism (McGrath 2005:98, 113; Lennox 2009:87) - although many scholars typify Darwin an agnostic rather than an atheist (McGrath ibid:104-105; Armstrong 2009:237).

This trend of criticism continued during the 20th century. French existentialist Jean-Paul Sartre (1905-1980) argued that even if God does exist, we should reject him because he endangers human freedom and responsibility (Armstrong 1999:443). Sartre's colleague, Albert Camus (1913-1960), concluded that life is absurd and that man has no other response than to rebel against this absurdity (Armstrong ibid:443; McGrath 2005:154-157).

At the end of the 20th century and the beginning of the 21th century, the flood of atheist criticism almost reached the power of a tsunami. Modern atheism became more and more sophisticated, aggressive, provocative, militant and antithetical, and developed into an anti-theistic life and worldview. Names to be mentioned here are, inter alia, Sam Harris (2006), Daniel Dennett (2007), Christopher Hitchens (2009), and especially Richard Dawkins, whose book The God delusion (2007) played an immense role in this new development.

As mentioned earlier, in South Africa the views of Claassen, Pellencin and Pietersen attracted attention. Atheism has developed into a radical antitheism movement.

The question may be raised whether South African atheists reflected on the ideology of apartheid during the years 1948-1994. I am not aware of any atheist who opposed and rejected the ideology of apartheid from an atheist perspective.

\section{Freedom of religion}

During the first three centuries of the Christian era, Christians were a minority group who experienced severe persecution. ${ }^{15}$ During the 4th century the situation changed drastically

15.See the persecutions under Nero (64), Decius (249-251), Valerianus $(257-258)$ and Diocletianus (303-311). See the formulation in Hebrew 11:35-38: Christians were tortured, faced jeers and flogging, chained, put in prison, stoned, and sawed in two. They went about in sheepskins and goatskins, destitute, persecuted, and mistreated. They wandered in deserts and mountains, in caves and holes in the ground. Other examples are John the Baptist and Paul who were beheaded, Stephen and James (the brother of Jesus) who were stoned to death, James (the postle) who was killed by a sword and Peter who was crucified upside-down. In addion, and Jeremiah stoned to death. Pietersen (2011:216) totally ignores these facts. In many instances he gives a totally distorted evaluation of the beliefs and lives of Christians (cf. Pietersen ibid:250, 266). 
when the emperor Constantine in $313 \mathrm{AD}$ granted official religious freedom to the church, followed by Theodosius, who in $380 \mathrm{AD}$ declared the catholic (Christian) faith to be the official religion of the Roman Empire. This close (and fatal) connection between state and church lasted for many centuries, through the Middle Ages, and had a devastating effect on the church's character and mission in the world. This 'theocratic' approach was finally brought to an end by the human rights movement, which started during the 16th and 17th century (John Locke and Thomas Hobbes) and reached a certain climax with the Declaration of Human and Civil Rights (France in 1789) and the Universal Declaration of Human Rights (United Nations Organisation in 1948; cf. Von Campenhausen 1971:9-15; Verkuyl 1948:163-237).

As stated earlier, the question we face today is how two opposing and conflicting worldviews like Calvinism and atheism can coexist in peace in local, national and world societies:

- How can they prevent permanent conflict, and even war?

- What does it mean when Calvinists and atheists refer to human rights and religious freedom?

- Will atheists feel comfortable when Christians proclaim the gospel of Jesus Christ and the message of the kingdom of God as the only hope for humanity, or do they view Calvinism (and Christianity) as a primitive, irrational and even dangerous worldview?

- Should Calvinists now reject the notion of 'theocracy' as an outdated and unbiblical concept, or should they accept it only as a confession of faith (God reigns through Christ) and not as a worldview that should be enforced by law in a pluralistic society? Because the gospel is indeed a gospel of freedom, which rejects any notion of enforcement and compulsion.

- South Africa only recently became an open society. How do Calvinists and atheists act and interact in this new situation?

Calvinism and atheism sharply differ as far as their worldviews are concerned with regard to God, man and science. Let us shortly investigate their approaches in this regard - although there are many more differences to highlight. For the purpose of this investigation, the abovementioned themes are deemed to be most important.

\section{Calvinism and atheism on God}

Calvinism and atheism differ sharply on the concept of God. Whilst in Calvinism faith in the living God lies at the heart of human existence and hope, atheism finds this idea irrational, unjustifiable, contradictory and dangerous.

\section{Atheism on God}

Atheism denies the reality of God, rejects the value of religion and argues that religion and faith are useless and even dangerous for the human mind and mankind.

Firstly, the concept of God is irrational. God cannot be proved by science and facts, and that which cannot be proved scientifically is irrational and therefore unacceptable. ${ }^{16}$ Because there is no God, prayers are useless (Dawkins 2007:85-90; Pietersen 2011:116, 274, 301-304, 354).

Secondly, the biblical notion of God is unacceptable, because the God of the Old Testament is a bloodthirsty God without love, destroying whole cities and their inhabitants (Dawkins 2007:51; Pellencin 2007:80-81; Pietersen 2011:38, 55, 272, 284-285, 318; Claassen \& Gaum 2012:316; Van Wyk, Nolte \& Atterbury 2011:149) ${ }^{17}$ Furthermore, the God of the New Testament is without justice, because he condemns innocent people to eternal damnation for temporary sins conducted by them (Pellencin ibid:140-143, 194-195). The notion of 'hell' is abhorrent as a 'doctrine of cruelty' (Russell 2002:20-24) - it is the most 'malicious and reprehensible doctrine' of classical Christianity (Pellencin ibid:194; cf. Claassen \& Gaum ibid:322-325, 359-360; Van Wyk et al. ibid:59-61, 64, 259, 274). According to Pietersen (ibid:292ff.), the Christian dogma of hell is of 'central importance' in Christianity - he refers ironically to the 'Good News of divine damnation' in this regard (Pietersen ibid:86, 338).

Thirdly, the idea of a God (and religion) is detrimental and dangerous to people (Pellencin 2007:18; Dawkins 2007:188$189,347)$. It evokes fanaticism and extremism - no kind of fanaticism is so radical, explosive and devastating as religious fanaticism. Religious wars and conflicts illustrate this approach vigorously.

The most important step to spiritual freedom, according to Pietersen (2011:277), is therefore to escape from the 'god fear' (theophoby), especially where children are concerned (Pietersen ibid:280). According to him, fear and ignorance are the two great evils in human life (Pietersen ibid:117, 141, 150, 352). ${ }^{18}$

\section{Calvinism on God}

These are not just simple accusations without any substance. What answers do Calvinists supply in this regard?

Firstly, Calvinists argue that atheists start with certain presuppositions (even preoccupations) that are not fully articulated, namely (naïve) rationalism and positivism. This epistemology (and worldview) departs from the presupposition that the human mind can discover and uncover the full truth through a process of verification and falsification (scientism). Atheism reduced the concept of 'reality' to immanent reality only, excluding any possibility of a transcendent reality (naturalism). Postmodernism has severely criticised this form of foundationalism. None of the

16.It is conceivable that in this context the theodicy question arises on the horizon How can an almighty and loving God allow so much pain and suffering in the world (Pietersen 2011:286, 288)? This question was dealt with in more detail in anothe article on atheism that was referred to earlier in this article (Van Wyk 2013). The biblical message is clear that the God of love is, whatever the circumstances may biblical message is clear that the God of love is, whatever the circumstances may be, always near those who trust him - assisting, strengthening and providing for them. His grace is always sufficient ( 2 Cor 12:9). He can even overturn a seemingly evil action into new opportunities (Joseph; Gn 50:20). For more details, see Van
de Beek (1984).

17.See Van Rooy (2009) in this regard.

18.For the same idea, see Van Wyk et al. $(2011: 19,27,54,64,65,138,257)$. 
great assumptions and presuppositions of atheism can be verified scientifically (cf. Nürnberger 2010:114-119). The concept of God and transcendence cannot be proved, or disproved either, because the 'existence' of God falls in a total different category than the existence of other created objects. God does not 'exist'. He 'is' - in a unique way. ${ }^{19}$

Secondly, turning to the God of the Old Testament, we always have to keep in mind the basic reiterated message of the Old Testament: God is a compassionate and gracious God, slow to anger, abounding in love and faithfulness (Ex 34:6; Ps 78:38; 86:15; 103:8; 111:4; 112:4; 145:8; Hs 2:18; J1 2:13; Jnh 4:2; Neh 9:17). ${ }^{20}$ 'He does not willingly bring affliction or grief to the children of men' (Lm 3:33). Everything taught in the Old Testament about God must be viewed from the perspective that God is a compassionate and an emphatic God (McGrath \& McGrath 2007:90; Peels 2011).

What then about the (temporal) destruction of Canaanite cities and eternal damnation of millions of people? With regard to the destruction of cities, we should keep in mind (Lennox 2011:117-142) that the Canaanites received a welldeserved punishment for their wickedness and atrocities (Dt 9:4; 'sacrifices of children to the idols', Dt 12:31). Furthermore, these punishments were extraordinary and God was patient with them for many centuries. Calvinists agree that in the person and work of Jesus Christ, we experience the highest and fullest illustration of the love and grace of a benevolent God.

The question about 'hell' in the Calvinist (Christian) tradition is more difficult to answer. On the one hand, the biblical message is clear on a last judgement - a God who simply overlooks all human atrocities and cruelties is no God. On the other hand, the question arises whether this final judgement is not disproportionate - eternal damnation for temporal sins. Theologians have considered many solutions in this regard:

- Universalism - in the end all will be saved.

- Annihilation of persistent evil-doers.

- Everybody can know God through a 'theology of nature'.

- 'Demythologising hell' - hell as a myth or metaphor. ${ }^{21}$

Calvinists find repose in the idea that the God of the Bible is a just and righteous God, and that the final judgement will be just and fair. No human judgement can be passed on those who never heard the gospel - this should be left in the hands of God (Bavinck 1930:708; Van den Brink \& Van der Kooi 2013:185, 668-669).

Thirdly, what about the atheist criticism that the concept of God is dangerous, with the implication that atheism is a

19.See Armstrong (1999:235) and Lennox (2009:182-184).

20.The Credo in Exodus 34:6-7 is the most-cited text in the Old Testament (Peels 2011:17). The 'patience' (long-suffering) of God reflects his heart and is the key characteristic of the God of the Old Testament (Peels ibid:19, 32, 43, 44) - it is the foundation of Israel's history (Peels ibid:31, 43). This is what distinguishes Israel's God from the revengeful gods of the surrounding nations (Peels ibid:45-46). Also see the detailed discussions in Copan (2011). For the New Testament, see Also see the $3: 9$.
Peter

21.Also see the recent remarks by Durand (2013b). healthy, encouraging and positive worldview? What atheists ignore repeatedly in this regard is the gross violations and transgressions of human rights and infringement on religious freedom by atheists like Stalin in Russia and Mao Zedong in China (Collins 2007:41-42; Lennox 2011:83-95). Looking at the track record of Calvinism, it must be admitted that there are many things to be ashamed of, for instance some South African theologians claiming Calvinism to justify apartheid (wrongly so), but no one with an open mind can ignore the many benefits brought about by Calvinism. Calvinism strongly influenced the development of the concept of democracy. ${ }^{22}$ Calvin himself campaigned for free medical services for the poor, supervision of the price of bread, wine and meat, regulation of labour hours, compulsory primary school attendance, retraining of the unemployed, assistance of refugees, et cetera (cf. Van Wyk 1983:22; Schulze 1985). Calvinists argue that to know and serve God forms the basis of a good and responsible life. This is true wisdom. ${ }^{23}$

However, Calvinists should always be on the alert for any kind of fanaticism and extremism in attitude and action. They should follow in the footsteps of Jesus Christ and proclaim the good news of a new world of peace, joy, justice and freedom, which dawned with the advent of Christ as Lord and Saviour, and the coming of the Holy Spirit, which would reach its final realisation with a new heaven and a new earth.

\section{Calvinism and atheism on man Atheism on man}

Atheism operates with a very optimistic anthropology: human beings are on top of the evolutionary process: intelligent, well-informed, sophisticated, self-sufficient and autonomous - on top of the world and universe.

According to atheism, human beings have no transcendent origin, ${ }^{24}$ because the theory of evolution explains everything about humans, their origin, their life and their destination. Darwin's theory of evolution meant the death knell to the rule of the god of the universe and the concept of a creator god (Pietersen 2011:123, 330). Human beings are the result of a process of mutation and natural selection (Pietersen ibid:121).

Human beings have insight in themselves and their environment without any transcendent suppositions (Pietersen 2011:187). Where there is no god to believe in, no revelation from above, no saviour and no sin, faith and superstition can only be described as an obstruction and handicap for a human being - a stance that forms the central theme of the book of Pietersen (ibid:94). It can even be demonstrated: the less faith, the more peace, according to Pietersen (ibid:53, 184).

22.Pietersen seems totally unaware of the fact that the idea of democracy was strongly stimulated by Calvinism (Vorster 2013:225-229). Muller (2012:97) also draws attention to this fact, with reference to J. Witte (2007).

23.See Deuteronomy 10:12, 13; Job 28:28; Psalms 111:10; Proverbs 1: 7; 9:10 and Ecclesiastes 12:13.

24.Pietersen (2011:125) rejects (without substantiation) the argument that the possibility for life to start on earth by chance is the same as when a multitude of possibility for life to start on earth by chance is the same as when a multitude of
monkeys would bang on computer key boards ending up writing a Shakespearean sonnet, as referred to by Flew (2008:75). 


\section{Calvinism on man}

Some people would argue that the anthropology of Calvinism is somewhat pessimistic, for man is so corrupt that he is wholly incapable of doing any good and inclined to all evil - unless something extraordinary happens (see Heidelberg Catechism [H.C.] 3.8, 23.60).

In my view, it is incorrect to typify Calvinists' anthropology as pessimistic - realistic would be more descriptive. It is realistic in this sense that nowhere on earth do we find any perfect, impeccable and irreproachable human being. That man or woman is an imperfect being - Calvinists refer to humans as sinful beings - is the only Christian dogma that can be verified scientifically (Chesterton 2006:10).

Calvinism has a multilateral perspective on humans, which implies that human beings are created as the image of God, but had fallen into sin and ought to be liberated and renewed again. Humans alienated themselves from God (and their fellowmen) in their effort to be like God, but God, in his grace, sent Jesus Christ to save humans from sin, demons and death. He also sent his Spirit to renew the inner life of humans and to guide them on their earthly journey to the great day of consummation. Hence, humans are corrupt, unless they are renewed by the Spirit of God (H.C. 3.8) - and even then the Christian life is but 'a small beginning' of obedience to God (H.C. 44.114).

What is intriguing in the Calvinist approach to human life is that it not only focuses on the salvation of the individual, but it also talks about the Christian's calling in society. Calvin argues that the spiritual kingdom of God 'is already initiating in us upon earth certain beginnings of the Heavenly Kingdom' (Inst. 4.20.2). Calvinists are in principle socially, politically and economically involved people. It is true that Calvin sometimes overemphasised the heavenly kingdom and future life, stating that the present life must be 'neglected', 'despised' and 'loathed' (Inst. 3.9.4) - although never 'hated'. Christians have a calling in society and they may even enjoy the present life in a responsible way (Inst. 3.10.1-6), but they should never forget that they are pilgrims to a new kingdom to come and should therefore always meditate on the future life. Calvin opted thus for a third way between asceticism and secularism.

Calvin's view on resistance against an unjust rule and tyranny is also important. He taught obedience towards state authorities. However, there may arise a point where active resistance becomes an option, for instance where religious freedom is transgressed (Inst. 4.20-31-31) - Calvin later also added national freedom (cf. Van Wyk 1991:117). It must be kept in mind that there is an enormous difference between the Calvinistic approach of a rebellion by lower authorities against unjust rulers, and that of a revolution organised by the people as propagated by the atheist Karl Marx (cf. Van Wyk ibid:121-122).

As far as economic life is concerned, Calvin is sometimes criticised of being the generator of capitalism (Max Weber), but this evaluation has been repudiated by many researchers as a misinterpretation (and overstatement) of Calvin and Calvinism (cf. Van Wyk 1983:23-24). That human beings are homo oeconomicus and should fulfil their economical duty in society, is clear from Calvin's approach - but all people at all times must be treated with love (Inst. 2.8.55, 3.7.6), with special reference to the poor.

\section{Calvinism and atheism on science}

\section{Atheism and science}

The atheist Pietersen is very critical about the idea of a trinitarian God, as Calvinists confess him, but he himself seems unaware of the fact that he introduces a new trinitarian 'god', namely intellect (reason), facts and science (knowledge). For that on which one puts unlimited trust, that is your ' $\operatorname{god}{ }^{2} .{ }^{2}$ 'In science only one thing matters, and that is facts' (Pietersen 2011:100). ${ }^{26}$

The only reality that exists is the measurable and observable reality $\left(\mathrm{p} .95^{27}\right)$. Atheism is based on observation and reason (p. 197-198, 202). Through reason, proof and logics one uncovers the truth (p. 21, 22, 115, 363). The claims of true science are expected to be observable, measurable, provable, repeatable and refutable (p. 117-122). Science conveys to us a naturalistic, mechanistic, materialistic and monistic reality indeed a deterministic universe (p. 116).

Science can answer all questions (p. 241-243), although aesthetical and ethical issues create some difficulties (p. 202, 305-317, 365-366). Yet, atheists do appreciate moral values like love, honesty, integrity and progress (p. 230, 244). But how and where do you discover these values? Through scientific methods on the basis of factual knowledge, Pietersen answers (p. 308). This method shows that the Ten Commandments and the Golden Rule do not work, and that the notion of 'respect' is more important than that of 'love' (p. 308-309).

However, if you take evolutionism and with it the notion of 'survival of the fittest' as central part of your worldview, it will be very difficult to arrive at an 'ethic of human dignity' - unless you drop your scientism when you deal with ethics.

Pietersen also approaches and evaluates the Bible in a typical scientific way. In his view, the Bible fails as 'a reliable source of historical and scientific facts' (p. 105; cf. pp. 259, 263).$^{28}$ The Bible consists of fictions and myths from the distant past ( $p$. 229).

Pietersen's approach to the Bible, however, is highly problematic. One of the key features of sensible hermeneutics

25.See Luther's explanation of the first commandment (Luther 1965:17).

26.Pietersen (p. 106) is afraid of being accused of positivism, but that's precisely the epistemology he followed. He sharply criticises postmodernism (p. 168-180), although he accepts the fact that our knowledge is limited and incomplete (p. 180, 241-243).

27.Where only page numbers are indicated, it refers to Pietersen (2011).

28.The histories of Israel, Abraham and Moses are doubtful. To argue today that Jesus never existed ( $p .121,159,232,254-255,263$ ) is almost absurd. Even non-biblical authors referred to him (Van der Watt 2010:154-168). 
and correct interpretation is that one should carefully consider the specific type and kind of literature that one investigates. One cannot interpret a book on astronomy ${ }^{29}$ as if it presents a lesson in philosophy or in the same way a book on faith and salvation (the Bible) and expect an exposition on science. ${ }^{30}$ The Bible does contain history, but also poetry, prophecy and apocalyptic writings - all within the broader framework of a story on liberation and renewal and hope.

Pietersen's (Greek) concept of truth (correspondence between statement and fact; p. 108), is not only one-sided, but also outdated. He supplies no evidence of any knowledge of the many different truth theories on the market plain (cf. Van Wyk 2001:71-105).

\section{Calvinism and science}

Whereas atheism accused Calvinism of opposing more or less every form of scientific research and investigation, Calvin himself was in full support of it and recommended and propagated it as far as possible. He viewed governance, economics, arts and science as (natural) gifts of the Spirit of God from which Christians (and also nonbelievers) may profit, giving thanks to God (Inst. 2.2.13-16).

The criticism of Calvinism against science is not directed at science as such, but against scientism - making science a new idol that rules over every facet of human life, solves all problems and unravels all truths - instead of science being an instrument in the hands of God for the benefit of his coming kingdom.

The idea of 'Christian science' (or even better, science according to a Christian perspective) must be viewed against this background: science for the benefit of mankind, in the light of the revelation of God, under the Lordship of Christ and for the promotion of the kingdom of God (cf. Stoker 1961:299-304). ${ }^{31}$

\section{Calvinism, atheism and freedom of religion \\ From theocracy to cooperation}

The idea of freedom of religion is closely related to that of human rights, ${ }^{32}$ the relation between state and church $^{33}$ and the concept of theocracy. ${ }^{34}$

29.Pietersen regrets the fact that there is no book in Afrikaans available that deals in detail with astronomy. Maybe he is unaware of the excellent book by Van Zyl (2002) on this subject.

30.Pietersen (p. 347, 366) shows great appreciation for the highly critical approach to the Bible and biblical message by the South African New Reformation Movement.

31.See Van der Walt (2010:302, 315), who argues that the PUCHE too easily and unnecessarily dropped its Christian character in 2003 - it was not unconstitutional to keep it (with reference to J.D. van der Vyver). It is a great irony that at the time when the (Calvinist) PUCHE dropped its Christian character, a new Christian Roman Catholic University was founded in Johannesburg in 1999, namely the St Augustine University of South Africa.

32.See Du Toit (1984, 1988), N. Vorster (2002, 2007:118), J.M. Vorster (2012) and Reformed Ecumenical Synod (1983:150-154).

33.Coertzen (2006b:135-140; 2006c:364), J.M. Vorster (2004:198-210; 2006:399-408) and Van Wyk (1991:213-244). Also see Van de Beek (2012:113-118, 135-140); Van den Brink and Van der Kooi (2013:468-474, 568-576).

34.J.M. Vorster (2004:213-219; 2006:392-399; 2007:151-156).
With regard to the relation between state and church, many models are possible, differing from a relation where state and church form an inseparable unity (theocracy), to the state dominating the church ('politocracy'), the church dominating the state ('ecclesiocracy'), church and state totally separated ('separatism'; peaceful or antagonistic), to state and church differentiated but in a relation of cooperation ('cooperatism').

There exists considerable consensus amongst Calvinist theologians today that in the modern world, consisting of many plural societies with different religious and irreligious worldviews, the best model for the state-church relation is that of differentiation of spheres of authority on the one hand, and cooperation on the other, where possible. ${ }^{35}$ This approach excludes the (Calvinistic or Neo-Calvinistic) model of a theocracy in its realistic form in a specific country, but does not exclude the confession of faith of the theocratic vision, namely that Christ rules over the universe (Mt 28:18). This option also does not exclude a possible conflict and confrontation between church and state in cases where the church is convinced that the state infringes on human rights, denies human dignity and overrides human freedom (as happened during the years of apartheid in South Africa). In such circumstances the church is called upon to deliver a prophetic witness in society (cf. N. Vorster 2002:463-496).

What is interesting in the new South African dispensation, are cases of the opposite position, namely that the state (the courts) may be of opinion that the church contradicts the Constitution as far as human rights of gay persons and women (in church offices) are concerned. What the outcome of this process would be, is still uncertain. It is lawful for churches to have internal statutes and regulations, but it is unclear what will happen in the end when those regulations are found to be in conflict with the Constitution. ${ }^{36}$

The much applauded Constitution of the Republic of South Africa of 1996 (South Africa 1996a) also contains a bill of rights (equality, human dignity and freedom; ch. 2), including an item on the freedom of religion, belief and opinion (ch. 2.15).

The relevant stipulations in the South African Constitution 1996 (South Africa 1996a) read as follows:

35.See J.M. Vorster $(2004: 211,221)$ : theocracy cannot function in a modern plura society and should be replaced by a constitutional democracy (cf. Van der Walt 2005:70). Muller (2012:103) agrees with Vorster that the new version of Article 36 of the Belgic Confession (adopted by the GKSA in 1982) corresponds with the 'active-plural model', which implies a distinction between state and church, but also a certain kind of cooperation. For another approach, see Coetzee (2006).

36.The gay-question raised some intense debates in the DRC in recent years (cf. Van Coller 2013). To mention just a few: Reverend Laurie Gaum (Cape Town, 2005 and 2007), music teacher Johan Strydom (Moreletapark, 2005 and 2008) and theological student Lulani Vermeulen (Stellenbosch 2011). The recent synod decisions of the DRC (2004 and 2007) disapprove a permanent relationship

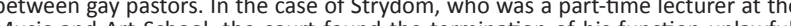
Music and Art School, the court found the termination of his function unlawful, because he could not be seen as a 'spiritual leader' in the congregation, although the court fully acknowledged the autonomy of the church in matters of doctrine and gay membership in office.

At the moment the gay question is also under discussion in the Methodist Church in South Africa. The service of Ecclesia de Lange, a Methodist minister who married in church to court been suspended by her church in 2010. She is now taking the church to court because of procedural mistake, but also because the action of the church is (in her view) unconstitutional and unlawful discrimination; (Jackson 2013; cf. Van Coller 2013). Her appeal to the Western Cape High Court has recently been turned down (Nel \& Vlok 2013). 
2.9.3 The state may not unfairly discriminate directly or indirectly against anyone on one or more grounds, including race, gender, sex, pregnancy, marital status, ethnic or social origin, sexual orientation, age, disability, religion, conscience, belief, culture, language and birth.

2.15 1. Everyone has the right to freedom of conscience, religion, thought, belief and opinion.

2. Religious observances may be conducted at state or state-aided institutions, provided that a. those observances follow rules made by the appropriate public authorities;

b. they are conducted on an equitable basis; and

c. attendance is free and voluntary.

2.29. 3. Everyone has the right to establish and maintain, at their own expense, independent educational institutions that -

a. do not discriminate on the basis of race;

b. are registered with the state; and

c. maintain standards that are not inferior to standards at compatable public educational institutions.

2.31. 1. Persons belonging to a cultural, religious or linguistic community may not be denied the right, with other members of that community a. to enjoy their culture, practise their religion and use their language; and

b. to form, join and maintain cultural, religious and linguistic associations and other organs of civil society.

From the abovementioned statements it is clear that the South African Constitution of 1996 differs from that of the United States of America in the fact that there is no radical separation between state and church (Coertzen 2006b:140). Van der Vyver (2007:77) remarks that the current South African Constitution can be described [...] as one of profound toleration and accommodation'. Therefore, the South African state should not be described as a secular state, but as a religious neutral state (Van der Vyver ibid:108; Du Plessis 2002:218) or, even better, as an impartial state (cf. Oosthuizen 2000:474; Smit 2006:634).

\section{Church and freedom of religion}

In the South African context, the concept of freedom of religion is mainly focused on two areas, namely the church and the school. The principles of freedom of religion are clearly defined in the South African Constitution of 1996 (South Africa 1996a), but the question remains how these principles should be practically applied in daily life situations. Coertzen (2002:191) correctly states that the South African Constitution 'provides only the fundamental framework for the freedom of religion'. Therefore, he deems further institutional guarantees necessary for the application thereof. Churches have to identify their constitutional rights (Coertzen 2008:61). Coertzen (2002:192, 195; 2012:835) also argues that churches (denominations) have to cooperate with each other as well as with other religious groups in this regard (cf. Coertzen 2006a). ${ }^{37}$

Although churches have the constitutional right to determine their own internal affairs (Verkuyl 1948:269-272; Smit 2006:639), Coertzen (2008:66) is of opinion that churches have the further obligation to determine:

1. where in their church orders, policies and practises are possible discrimination;

2. whether this discrimination is possibly unfair; and

3. demonstrate what is reasonably not unfair (e.g. abortion, gay marriages, women in office).

Coertzen himself took the initiative to develop The South African Charter of Religious Rights and Freedoms, which was endorsed on 21 October 2010 by 24 Christian denominations and religious bodies (Coertzen 2012:845-850). The aim was to submit the charter to parliament to be accepted as a law of the country.

It is important to pay attention to some of the key features in this Charter:

Art. 3.1: The state must create a positive and safe environment for the exercise of religious freedom, but may not promote, favour or prejudice a particular faith, religion or conviction, and may not indoctrinate anyone in respect of religion.

Art. 4.4: Every person has the right to conduct singlefaith religious observances, expression and activities in state or state-aided institutions [followed by certain provisions].

Art. 7: Every person has the right to be educated or to educate their children, or have them educated, in accordance with their religious or philosophical convictions.

Art. 7.2: Every educational institution may adopt a particular religious or other ethos, as long as it is observed in an equitable, free, voluntary and non-discriminatory way, and with due regard to the rights of minorities.

Art. 7.3: Every private educational institution established on the basis of a particular religion, philosophy or faith may impart this religious convictions to all children enrolled in that institution.

Art. 8: Every person has the right to receive and provide religious education, training and instruction.

Such a charter could be of great assistance for churches and the spreading of the gospel. There is something very important not to be forgotten by churches, however: during

37 with regard to cooperation between Christians and non-Christians, also see Van den Brink and Van der Kooi (2013:225); Küng (2012:19-41, 84-97). In 1982-1983 when a tricameral parliament between White people, Mixed race and Indian people was established in South Africa, many Calvinists rejected this developmen with the argument that Christians and non-Christians should not cooperate in politics - sometimes with reference to 2 Corinthians 6:14-16. In 1982 Dr A.P. reurnicht with 21 members of Parliament broke away to form the Conservative Party (Giliomee 2003:603). 
large periods of history, Christianity was a persecuted faith (cf. Heb 11:35-38). Christ warned his followers: 'If they persecuted me, they will also persecute you' (Jn 15:20). These words are confirmed in 2 Timothy 3:12: 'Everyone who wants to live a godly live in Christ Jesus will be persecuted.' In short, Christians must never use the concept of religious freedom to develop a non-active, non-influential, faceless and sloppy kind of Christianity. The blood of martyrs is the seed of the church. A prosperity gospel is an insipid gospel (cf. Van der Walt 2005:77-78). ${ }^{38}$

\section{School and freedom of religion ${ }^{39}$}

We now turn to the question about religious freedom in public and private schools.

Hans Pietersen (2011:346) is a fervent opponent of religious education in South African schools, because faith 'stupefies' children. ${ }^{40} \mathrm{He}$ believes that religious education should be prohibited in public schools and be restricted to parents, churches and private schools (p. 197, 277, 282, 321, 367). State schools must be secular (p. 164), Bible instruction in these schools is wrong (p. 182, 256) and the (Calvinist) indoctrination of faith in state schools must be stopped (p. 351, 354, 363). Pietersen pleads for even-handling of all religious groups in schools (p. 285, 357). ${ }^{41}$ The subtone of Pietersen's approach, however, is because religion is degrading and 'stupefying', the less of it at (public) schools, the better. Is this approach not an overstatement and overreaction?

Van der Vyver (2007:94) remarks that in public education, South Africa remains favourably disposed toward promoting spiritual values in the minds of young people, and does so through the good offices of state institutions'. In addition (Van der Vyver ibid):

Religion [in South Africa] is not a political taboo, but the Constitution requires even-handedness in dealings with religion and religious institutions. South African law thus, for example, permits religious observances in state and state-aided schools, subject to the principle of voluntary participation in such observances and affording to all religions with substantial support in the concerned school district a proportional share in conducting and participating in the religious ceremonies. ${ }^{42}$ (p. 108)

The South African School Act (South Africa 1996b) stipulates that 'the governing body of a public school must adopt a code

38.Also see Ellul (1976:439): "Christians must never claim a privileged position in society.'

39.See the different approaches in Du Toit and Krüger (1998) - especially Kruger (1998).

40.Pietersen refers here to a school struggle in Stellenbosch (p. 64-71).

41.Pietersen also blames Calvinism for slavery, xenophobia and apartheid (p. 180, 223,310 ). Pietersen (p. 71) also refers to the establishment of a new organisation OGOD (Organisasie vir Godsdienste-Onderrig en Demokrasie), which should keep a watching eye on religious education in public schools.

42.Personal conversations with Prof. Marinus Wiechers, an expert on constitutional topics, in May 2013 confirms this view. Also see Swart (2003) and Malherbe (2009). Oosthuizen (2000:470) refers to a court case in 1998 where the court decided that article 15.2 of the South African Constitution deals with the observance of religion at school and not the education thereof. of conduct for the learners after consultation with learners, parents and educators of the school'.$^{43}$

The same School Act of 1996 stipulates that any person may establish and maintain an independent school (s. 45), but it must be registered by the Head of the Department, standards must be comparable with public schools (s. 46[3][a]) and admission must be free from discrimination on the grounds of race (s. 46[3][b]). Van der Walt (2005:75), however, is of opinion that the present South African government discriminates against private schools, because they only receive $30 \%$ state subsidy whilst public schools receive $98 \%$.

A few case studies may illustrate the present debate on religious freedom in South African schools.

In a German school in Pretoria in 1998, a student took issue with the school association for being compelled to attend the religious classes. The court rejected the appeal because the student had subjected herself to the school's rules and regulations when she enrolled as a student (cf. Van der Vyver 2007:95).

In another case (the 'Prince' case) in 2002, the South African Constitutional Court declined to make an exception in favour of persons (Rastafarians) possessing or using cannabis (dagga) for religious purposes, which illustrates that the right to self-determination is not absolute (Van der Vyver 2007:95-96). Quite recently a judge of the Free State High Court instructed a school in Welkom to readmit a student (Radebe) who was expelled because of her Rasta-dreadlocks (Van Rooyen 2013). ${ }^{44}$

In summary, whilst Calvinists argue that the good news of the new kingdom of God is a healthy and liberating message for humans, including children, atheists are of opinion that faith and religion, also the Christian and/or Calvinistic faith, is irrational and dangerous, especially for children. If you follow this last option, it will be difficult to escape the consequence that religion should be restricted, if not banned, also from public schools. However, if you do that, you have simply exchanged the roles and replaced an old tyranny (Calvinism as state religion) by a new one (atheism as state 'religion'). Sometimes one gets the impression that atheists would only be satisfied if 'Christian-national' schools are replaced by 'atheist-national' schools. The South African Constitution, however, is clear on all these approaches.

\section{Conclusion: A new urgent debate}

1. The debate between Calvinists/Christians and (new) atheists has only recently started and it should be continued in an attitude of openness, dignity and objectivity. Christians are called upon to profess a witness

43.In a High Court case in 2013 in Johannesburg, the court reaffirmed the authority of the governing bodies of public schools with regard to the admission of scholars (Rademeyer 2013).

44. For the opposite stance, see the French law of 2004, which does not allow Christian children to wear necklaces with a cross and Muslim children to wear a veil (hijab; J.M. Vorster 2007:161). 
of the hope that inspires them (cf. Van den Brink \& Van der Kooi 2013:59; Küng 1991). All people, Christians and non-Christians, should interact with one another in an attitude of respect and decency and should refrain from disparaging and insulting comments. ${ }^{45}$ Mutual discourses should bear witness of flair and goodwill, and be free of caricature. All people must aim for the well-being of humanity and the wholeness of creation.

2. Atheism is a wake-up call to Christians and/or Calvinists to do introspection and to live authentic Christian lives. As long as our deeds contradict our confession of love and hope, the Christian message will be a stumbling block to atheists. ${ }^{46}$

3. Atheism reminds us of the fact that we should use the Bible in a correct and meaningful way and that we should avoid the extremes of fundamentalism (biblicism) as well as liberalism. The centre of the Bible is Jesus Christ, God's last and final word to the world (Heb 1:1-2). In this regard a new investigation of the gay-question is of great importance. ${ }^{47}$

4. Atheism opened up the great debate in a new way regarding the relation between science and theology, reason and faith, which must be welcomed. ${ }^{48}$ It also emphasises the relevance of the debate on a 'theology of creation' (cf. McGrath 2008).

5. We have to keep in mind that the development of the South African Constitution has a long history and was influenced by many value systems, including Calvinistic values. In many instances the Constitution does not contradict Christian and/or Calvinist ethics, but provides a vivid illustration thereof.

6. The constitutional right of freedom of religion for Christians and/or Calvinists must never lead to a saltless Christianity in which the willingness to suffer for the truth of the gospel has disappeared.

45.See the following disparaging references in the book of Pietersen (2011): bidbendes (bl. 7), godsverknogtes (bl. 26, 126, 207, 320), geloofsverknogtes (bl. 28), Bybelbeheptes (bl. 47, 127), absurditeite (bl. 100), leuenaars (bl. 147) aartappelprofete en pleisterpredikers (bl. 183), kafpraters (bl. 221), kanselkaf (bl. 265), Jesusfratse (bl. 329) and Bybelbliksems (bl. 348).

46.It is a shameful fact that (Protestant) Christianity many times dismally capitulated before the onslaught of the ideology of nationalism. A few examples will illustrat this statement: (1) Anglicanism (in England and South Africa) failed to protest against the 'crimes against humanity' that took place during the Anglo Boer Wa (1899-1902), during which period 35000 women and children (and thousands of black people) died in concentration camps. The Anglican Church(es) never released any confession of guilt in this regard, although, it was an Anglican woman, Emily Hobhouse, who uncovered many atrocities of the British army and protested against these evils. (2) Also, Lutheranism failed in Germany during World War II (1939-1945) to protest loud enough against Nazism when 6 million Jews were killed in concentration camps, although, it was a reformed theologian, Karl Barth, who formulated the Barmen Declaration (1934), which was accepted by the Confessing Church in Germany (Busch 1976.258). (3) Wuring the years of apartheid in South Africa (1948-1994) (Busch 1976.258). (3) During the years of apartheid in South Africa (1948-1994) when the ideology of apartheid was theologically ustified, also Calvinism failed to a large extent to oppose this ideology, although, it Confession (Jonker 1998:162), which was adopted by the NG Sendingkerk in 1986.

47.Snyman (2006:979) argues that the material in Leviticus refers to heterosexual persons who participated in homosexual practices (in family circles). Du Toi (2007:169) concurs that in Romans 1 Paul refers to 'unnatural relations', that is, heterosexual men and women who practised homosexual deeds, although Janse van Rensburg (2006) differs. This implies that there are at least three options in this regard: (1) homosexuals live a life of promiscuity with other homosexuals, which should be rejected on moral grounds, (2) heterosexuals practise homosexua activities with other heterosexuals, which is rejected in both the Old Testament (Snyman 2006) as well as the New Testament (Du Toit 2007), and (3) a homosexual lives in love and trust with another homosexual, a situation which is not referred to in the Bible - thus the argument goes. Van de Beek (2012:272-273) opts for to in the Bible - thus the argument goes. Van de Beek (2012.272-273) opts for situation ethics on this matter. It would

48.Van Huyssteen (2006) focused a lot on this topic - see his latest book Alone in the world?. Also see Nürnberger (2011), Durand (2013a), Conradie (2013) and Van de Walt (2006).

\section{Acknowledgements Competing interests}

The author declares that he has no financial or personal relationship(s) that may have inappropriately influenced him in writing this article.

\section{References}

Armstrong, K., 1999, A history of God: From Abraham to the present: The 4000-year quest for God, Vintage Books, London.

Armstrong, K., 2009, The case for God: What religion really means, The Body Head, London.

Badenhorst, F.G., 1939, Die rassevraagstuk, veral betreffende Suid-Afrika, in die lig van die Gereformeerde etiek, Noord-Hollandsche Uitgewers, Amsterdam.

Bavinck, H., 1930, Gereformeerde Dogmatiek, vol. 4, Kok, Kampen.

Brits, D. \& d'Assonville, V., 2009a, 'Politics and Social life', in H.J. Selderhuis (ed.), The Calvin Handbook, pp. 437-448, Eerdmans, Grand Rapids.

Brits, D. \& d'Assonville, V., 2009b, 'Calvin in Africa', in H.J. Selderhuis (ed.), The Calvin Handbook, pp. 505-512, Eerdmans, Grand Rapids.

Busch, E., 1976, Karl Barths Lebenslauf: Nach seinen Briefen und autobiographischen Texten, Kaiser, München.

Calvin, J., 1960, Institutes of the Christian Religion (in two volumes), transl. F.L. Battles, Westminster John Knox Press, Louisville.

Calvyn, J., [1991] 1992, Institusie van die Christelike Godsdiens 1559, vert. H.W Simpson, CJBF, Potchefstroom.

Chesterton, G.K., [1908] 2006, Orthodoxy, Hendrickson Publishers, Peabody.

Claassen, G., 2008, Geloof, bygeloof en ander wensdenkery: Perspektiewe op ontdekkings en irrasionaliteite, Protea, Pretoria.

Claassen, G. \& Gaum, F. (eds.), 2012, God? Gesprekke oor die oorsprong en uiteinde van alles, Tafelberg, Kaapstad.

Coertzen, P., 2002, 'Freedom of religion and religious education in a pluralistic society', Nederduitse Gereformeerde Teologiese Tydskrif 43(1\&2), 185-196.

Coertzen, P., 2006a, 'Godsdiensvryheid - 'n Uitdaging en geleentheid vir kerke en godsdiensgemeenskappe in Suid-Afrika', Tydskrif vir Geesteswetenskappe 46(2), godsdiens: $198-209$.

Coertzen, P., 2006b, 'Kerk en staat: Die optimum verkondiging vir godsdiensvryheid' Nederduitse Gereformeerde Teologiese Tydskrif 47(1\&2), 134-142.

Coertzen, P., 2006c, 'Kerke en transformasie in Suid-Afrika', Nederduitse Gereformeerde Teologiese Tydskrif 47(3\&4), 361-372.

Coertzen, P., 2008, 'Being church and freedom of religion - The function and ambit of religious freedom', Nederduitse Gereformeerde Teologiese Tydskrif 49(3\&4) $60-68$.

Coertzen, P., 2012, 'Religious freedom and a South African charter of religious rights and freedoms', in E. Van der Borght \& P. van Geest (eds.), Strangers and pilgrim on earth: Essays in honour of Abraham van de Beek, pp. 833-851, Brill, Leiden.

Coetzee, C.F.C., 2006, 'Godsdiensvryheid in die lig van Artikel 36 NGB', Nederduitse Gereformeerde Teologiese Tydskrif 47(1\&2), 143-157.

Collins, F., 2007, The language of God: A scientist presents evidence for belief, Pocket Books, London.

Conradie, E.M., 2013, Lewend en kragtig? In gesprek oor ... God se handelinge in die wêreld, Bybel-Media, Wellington.

Copan, P., 2011, Is God a moral monster? Making sense of the Old Testament God, Baker, Grand Rapids.

Cottret, B., 2000, Calvin: A biography, transl. M.W. McDonald, Eerdmans, Grand Rapids.

Dawkins, R., 2007, The God delusion, Black Swan, London.

De Klerk, W.A., 1976, The puritans in Africa: A story of Afrikanerdom, Penguin, Harmondsworth.

De Klerk, F.W., 1998, Die laaste trek - 'n Nuwe begin, Human \& Rousseau, Kaapstad.

Dennett, D., 2007, Breaking the spell. Religion as a natural phenomenon, Penguin, London.

De Villiers, J., 2009, 'Vrydenkers sê hoekom hulle skole kan dophou', Rapport, 25 October, bl. 5.

Du Plessis, L.M., 2002, 'Grondwetlike beskerming vir godsdiensregte as groepsregte in Suid-Afrika', Nederduitse Gereformeerde Teologiese Tydskrif 43(1\&2), 214-229.

Durand, J.J.F., 1985, 'Afrikaner piety and dissent', in C. Villa-Vicencio \& J.W. de Gruchy (eds.), Resistance and hope: South African essays in honour of Beyers Naudé, pp. 39-51, David Philip, Cape Town

Durand, J, 2013a, Evolusie, wetenskap en geloof: 'n Biografiese inleiding tot die denke van Teilhard de Chardin, Bybel-Media, Wellington.

Durand, J., 2013b, 'Enkele perspektiewe oor die vraag na die hel', Kerkbode, 21 Junie, bl. 8-9. 
Du Toit, A., 2007, 'Maar die grootste hiervan is die liefde - Oor homoseksualiteit in Romeine 1', in C. Vos \& D. Human (eds.), Liefde is die grootste: Oor erotiek en seksualiteit, bl. 161-171, Protea, Pretoria.

Du Toit, C.W. \& Krüger, J.S. (eds.), 1998, Multireligious education in South Africa: Problems and prospects in a pluralistic society, University of South Africa, Pretoria.

Du Toit, D.A., 1984, Menseregte, Tafelberg, Kaapstad.

Du Toit, D.A., 1988, Die mens en sy regte, Zebra, Kaapstad.

Du Toit, J.D., 1977, Totius Versamelde Werke: Die staat, maatskappy, taal en kultuur, vol. 7, Tafelberg, Kaapstad.

Duursema, G.J., 2012. 'Deurdagte koerswysiging:'n Biografiese bibliografie van Willem Daniël Jonker 1929-1955', MTh-verhandeling, Fakulteit Teologie, Departement Ekklesiologie, University of the Free State.

Ellul, J., 1976, The ethics of freedom, transl. G.W. Bromiley, Eerdmans, Grand Rapids. Engelbrecht, B., 1978, God en die politiek, Butterworth, Durban.

Engelbrecht, B., 1982, Ter wille van hierdie wêreld: Politiek en Christelike heilsbelewing in Suid-Afrika, Tafelberg, Kaapstad.

Flew, A., 2008, There is a God: How the world's most notorious atheist changed his mind, HarperCollins, New York.

Gaum, F., 2011, Fluit-fluit die kerk is uit?, Bybel-Media, Wellington.

Giliomee, H., 2003, The Afrikaners: Biography of a people, Tafelberg, Cape Town.

Harris, S., 2006, Letter to a Christian nation, Alfred A. Knopf, New York.

Hitchens, C., 2009, God is not great, Atlantic Books, London.

Jackson, N., 2013, 'Sy's 'n moderne Jeanne d'Arc', Beeld, 18 Mei, bl. 8.

Janse van Rensburg, F., 2006, 'Die tydgerigtheid van die Bybel en die etiek van Bybellees: Respons op die artikel van Gerrie Snyman', In die Skriflig 40(4), 745769.

Jonker, W., 1998, Selfs die kerk kan verander, Tafelberg, Kaapstad.

Kearney, P., 1991, 'Freedom of thought, conscience and religion', in M. Robertson (ed.), Human rights for South Africans, pp. 123-130, Oxford University Press, Oxford.

Küng, H., 1991, Global responsibility: In search of a new world ethic, SCM Press, London.

Küng, H., 2012, Handbuch Weltethos: Eine Vision und ihre Umsetzung, Piper, München. Kuyper, A., 1880, Souvereiniteit in eigen kring, Kok, Kampen.

Kuyper, A., 1959, Het Calvinisme: Zes Stone-lesingen, Kok, Kampen.

Kruger, J.S., 1998, 'Why multireligious education?', in C.W. du Toit \& J.S. Kruger (eds.) Multireligious education in South Africa: Problems and prospects in a pluralistic society, pp. 32-50, Unisa, Pretoria.

Lennox, J.C., 2009, God's undertaker: Has science buried God?, Lion Hudson, Oxford.

Lennox, J.C., 2011, Gunning for God: Why the new atheists are missing the target, Lion Hudson, Oxford.

Luther, M., 1965, Luther's Grote Catechismus, transl. P. Boendermaker, Kok, Kampen.

Malherbe, R. 2009, 'Debat in godsdiens in skole is maar ... tonetrap en toutrek', Rapport, 27 September, bl. 21.

McGrath, A.E., 1991, A life of John Calvin: A study in the shaping of Western culture, Basil Blackwell, Oxford.

McGrath, A., 2005, The twilight of atheism: The rise and fall of disbelief in the modern world, Random House, London.

McGrath, A. \& McGrath, J.C., 2007, The Dawkins delusion? Atheist fundamentalism and the denial of the Divine, InterVarsity Press, Downers Grove.

McGrath, A., 2008, The open secret: A new vision for natural theology, Blackwell, Oxford. http://dx.doi.org/10.1002/9781444301205

Meiring, P., 1999, Kroniek van die Waarheidskommissie: Op reis deur die verlede en die hede na die toekoms van Suid-Afrika, Carpe Diem, Vanderbijlpark.

Mollett, T., Grundling, E. \& Van Heerden, E. (eds.), 2004, Die omstrede God: Bestaan God of nie?, African Sun Media, Stellenbosch.

Muller, D.F., 2012, 'Die owerheid se ingesteldheid ten opsigte van godsdiens: Die geskiktheid van die aktief-plurale opsie vir die toepassing van artikel 36 van die Nederlandse Geloofsbelydenis', In die Skriflig/In Luce Verbi 46(1), art \# 37, 11 pages.

Naudé, C.F.B., 1985, 'Op weg naar een belijdende kerk', in H. Berkhof et al. (eds.), Met de moed der hoop: Opstellen aangeboden aan dr. C.F. Beyers Naudé, pp. 167-179, Ten Have, Baarn.

Naudé, C.F.B., 1995, My land van hoop: Die lewe van Beyers Naudé, Human \& Rousseau, Kaapstad.

Nel, C.A. \& Vlok, M., 2013, 'Geskorste gay leraar misluk in hof', Beeld, 26 Junie, bl. 3.

Niesel, W., 1980, The theology of Calvin, transl. H. Knight, Baker Book House, Grand Rapids.

Nürnberger, K., 2010, Richard Dawkin's God delusion: A repentant refutation, Xlibris, London.

Nürnberger, K., 2011, Regaining sanity for the earth: Why science needs 'best faith' to be responsible. Why faith needs 'best science' to be credible, Cluster, Pietermaritzburg. http://dx.doi.org/10.4102/koers.v65i4.485

Oosthuizen, I.J., 2000, 'Die reg op godsdiensvryheid in Suid-Afrikaanse skole', Koer 65(4), 461-475.
Peels, H.G.L., 2011, Traag tot toorn: Een onderbelicht aspect van het oudtestamentisch godsbeeld, Theologische Universiteit, Apeldoorn.

Pellencin, A.L., 2007, Ateïsme: Die saak teen God, Publiself Uitgewers, Pretoria.

Pietersen, H., 2011, Die vrese van ons vaders: Geloof, onderrig en die Afrikanerkind, Griffel Media, Kaapstad.

Pretorius, F. (ed.), 2012, Geskiedenis van Suid-Afrika: Van voortye tot vandag, NBUitgewers, Tafelberg.

Rademeyer, A., 2013, 'Skoolrade kry goeie nuus', Beeld, 29 Augustus, bl. 1.

Reformed Ecumenical Synod, 1983, RES Testimony on Human Rights, Reformed Ecumenical Synod, Grand Rapids.

Ridderbos, N.H., 1962, Korte Verklaring der Heilige Schrift: De Psalmen: Part 1 (1-41), Kok, Kampen.

Russell, B., [1957] 2002, Why I am not a Christian - And other essays on religion and related subjects, Routledge, London.

Ryan, C., 1990, Beyers Naudé: Pilgrimage of faith, Eerdmans, Grand Rapids.

Schulze, L., 1985, Calvin and 'social ethics': His views on property, interest and usury, Kital, Pretoria.

Selderhuis, H.J. (ed.), 2008, The Calvin handbook, transl. H.J. Baron, J.J. Guder, R.H. Lundell \& G.W. Scheeres, Grand Rapids, Eerdmans.

Selderhuis, H.J., 2009, John Calvin: A pilgrim's life, transl. A. Gootjes, InterVarsity Press, Nottingham

Smit, D.J., 2007, Essays in public Theology: Collected essays I, Sun Press, Stellenbosch.

Smit, J., 2006, 'Die kerk se regsposisie in Suid-Afrika in die lig van godsdiensvryheid - Gereformeerd-kerkregtelik gesien', Nederduitse Gereformeerde Teologiese Tydskrif 47(3\&4), 633-651.

Smith, N., 2010, Die dood van die God van my vaders: Hoe die lewe in die township Mamelodi my godsbeskouing verander het, Griffel Media, Kaapstad.

Snyman, S.D., 2006, 'Help Levitikus 18:22 en 20:13 die (NG) Kerk in die debat oor homoseksualiteit?', Old Testament Essays 3, 968-981.

South Africa, 1996a, Constitution of the Republic of South Africa, Act 108 of 1996, Government Printer, South Africa.

South African Government, 1996b, South African Schools Act, 84 of 1996, Government Printer, Pretoria.

Stoker, H.G., 1961, Beginsels en metodes in die wetenskap, Pro Rege, Potchefstroom.

Strydom, J.G., 1941, 'Die rassevraagstuk in Suid-Afrika', in H.G. Stoker \& J.D. Vorster (eds.), Koers in die krisis, bl. 243-255, Pro Ecclesia, Stellenbosch.

Strydom, J.G., 1942, Die rassevraagstuk en die toekoms van die blankes in Suid-Afrika, NGK in die OVS.

Swart, F. 2003, 'Godsdiens hét 'n plek in die skool', Kerkbode, 23 May, bl. 10.

Van Coller, H., 2013, 'Homoseksuele predikante: 'n Regs- en morele dilemma', besigtig 10 October 2013, by http://www.litnet.co.za

Van de Beek, A., 1984, Waarom? Over lijden, schuld en God, Callenbach, Nijkerk.

Van de Beek, A., 2012, Lichaam en Geest van Christus: De theologie van de kerk en de Heilige Geest, Meinema, Zoetermeer.

Van den Brink, G. \& Van der Kooi, C., 2013, Christelijke Dogmatiek: Een Inleiding, Boekencentrum, Zoetermeer.

Van der Vyver, J.D., 2007, 'The contours of religious liberty in South Africa', Emory International Law Review 21(1), 77-110.

Van der Walt, B.J., 2005, 'Godsdiensverskeidenheid, -onverdraagsaamheid en -vryheid: 'n Prinsipiële besinning', In die Skriflig 39(1), 53-80. http://dx.doi. org/10.4102/ids.v39i1.374

Van der Walt, B.J., 2006, 'Hedendaagse populêre voorligting oor die verhouding tussen die manlike en vroulike geslag: Besinning oor evolusionistiese etiek', In die Skriflig 40(2), 265-284. http://dx.doi.org/10.4102/ids.v40i2.343

Van der Walt, B.J., 2010, 'Besit waardes rigtinggewend-normatiewe waarde? 'n Beoordeling van die Noordwes-Universiteit se waardeprojek', Koers 75(2), 293323. http://dx.doi.org/10.4102/koers.v75i2.84

Van der Watt, J. (ed.), 2010, Wie sê julle is Ek?, Christelike Uitgewers Maatskappy, Vereeniging.

Van Huyssteen, J.W., 2006, Alone in the world? Human uniqueness in science and theology, Eerdmans, Grand Rapids.

Van Rooy, H.F., 2009, 'Psalm 137 en die beryming van wraakpsalms', In die Skriflig 43(3), 585-600. http://dx.doi.org/10.4102/ids.v43i3.238

Van Rooyen, J.H.P., 1964, Kerk en staat: 'n Vergelyking tussen Kuyper en Van Ruler, VRB Kleine, Groningen.

Van Rooyen, M., 2013, 'Skool kry bloedneus oor meisie se lokke', Beeld, 18 Mei, bl. 1. Van Ruler, A.A., 1971, Theologisch Werk Deel III, Nijkerk, Callenbach.

Van Wyk, D., Nolte, C. \& Atterbury, L., 2011, Hier staan ek ... maar ek kan nie sê wie ek is nie en ek is nie alleen nie, Griffel Media, Kaapstad.

Van Wyk, J.H., 1983, Calvyn oor die Christelike lewe, NG Kerkboekhandel, Pretoria.

Van Wyk, J.H., 1991, Moraliteit en verantwoordelikheid: Opstelle oor politieke etiek, $\mathrm{PU}$ vir $\mathrm{CHO}$, Potchefstroom.

Van Wyk, J.H., 1993, 'Homo Dei: 'n Prinsipiële besinning oor enkele mensbeskouings, waaronder dié van Calvyn', In die Skriflig 27. (Supplementum 1). 
Van Wyk, J.H., 1998, Etiek in eenvoud: Gesprekke oor morele vraagstukke, PTP, Potchefstroom.

Van Wyk, J.H., 2001. Etiek en eksistensie - In koninkryksperspektief, PTP, Potchefstroom.

Van Wyk, J.H., 2006, 'Reformasie en onderwys(-ers): Enkele teologiese perspektiewe', In die Skriflig 40(2), 339-353.

Van Wyk, J.H., 2013, 'Die uitdaging van die ateïsme en antiteïsme: 'n Teologiese gesprek met Armando Pellencin oor sy boek Ateïsme: Die saak teen God (1\&2)' In die Skriflig 47(1), Art. \#536.

Van Zyl, J.E., 2002, Ontsluier die heelal: 'n Inleiding tot die sterrekunde, Protea, Pretoria.

Verkuyl, J., 1948, Enkele aspecten van het probleem der godsdienstvriiheid - In betrekking tot de plaats en arbeid van die christelijke kerken in Asië, Kok, Kampen.

Von Campenhausen, A., 1971, Religionsfreiheit: Oekumenische Bestandaufnahme nach dem II. Vatikanischen Konzil, Vandenhoeck \& Ruprecht, Göttingen.

Vorster, J.M., 2004, Ethical perspectives on human rights, PTP, Potchefstroom.

Vorster, J.M., 2006, 'Christelike gesindhede en ander godsdienste', In die Skriflig 40(30), 389-412.

Vorster, J.M., 2007, Christian attitude in the South African liberal democracy, PTP, Potchefstroom.
Vorster, J.M., 2012, 'A Christian perspective on human dignity', in E. Van der Borght \& P. van Geest (eds.), Strangers and pilgrims on earth: Essays in honour of Abraham van de Beek, pp. 817-831, Brill, Leiden.

Vorster, J.M., 2013, 'Calvin and human dignity', in H. van den Belt (ed.), Restoration through redemption: John Calvin revisited, pp. 215-229, Brill, Leiden. http:// dx.doi.org/10.1163/9789004244672_015

Vorster, N., 2002, 'Kerk en menseregte binne 'n regstaat', ThD-verhandeling, PU vir $\mathrm{CHO}$, Potchefstroom

Vorster, N., 2007, Restoring human dignity in South Africa: Christian anthropology in a new dispensation, PTP, Potchefstroom.

Vosloo, R., 2013, 'Calvin's theological heritage in South Africa: Enganging an ambivalent, contested and promising legacy', in $\mathrm{H}$. van den Belt (ed.), Restoration through redemption: John Calvin revisited, pp. 247-270, Brill, Leiden. http:// dx.doi.org/10.1163/9789004244672_017

Wallace, R.S., 1988, Calvin, Geneva, and the Reformation, Scottish Academic Press, Edinburgh.

Wendel, F., 1978, Calvin: The origin and development of his religious thought, transl. P. Mairet, William Collins Sons, London.

Witte, J., 2007, The reformation of rights, law, religion, and human rights in early modern Calvinism, Cambridge Universty Press, Cambridge. 